\title{
Spinal Injury Related to Birth
}

National Cancer Institute

\section{Source}

National Cancer Institute. Spinal Injury Related to Birth. NCI Thesaurus. Code C101278.

An injury to the spine sustained during the birthing process. 